\title{
МОДЕЛЬ РОЗВИТКУ ПРОФЕСІЙНОЇ ВІДПОВІДАЛЬНОСТІ В МАЙБУТНІХ ФАХІВЦІВ РАКЕТНО-КОСМІЧНОЇ ГАЛУЗІ
}

УДК: $159.947 .23: 331.543: 629.7$

\section{Кроика Наталія Петрівна}

\author{
Аспірантка кафедри практичної психології 3 - \\ порізького національного університету, м. За- \\ поріжжя (Україна) \\ ORCID ID: https://orcid.org/0000-0001-8026-0168
}

\begin{abstract}
Анотація. В статті обтрунтовано необхідність розробки моделі та впровадження програми иілеспрямованого розвитку професійної відповідальності в майбутніх фахівиів ракетно -космічної галузі. На підставі теоретичних засад дослідження побудовано експериментальну модель розвитку професійної відповідальності майбутніх фахівиів ракетно-космічної галузі. Модель містить психологічні умови, тематичні блоки та розвивальні заходи програми, психологічну структуру професійної відповідальності, критерії розвитку ї компонентів. Розкрито динамічний аспект розвитку етичної свідомості, що втілюється у взаємозв 'язку всіх складових моделі. Визначено психологічні умови розвитку професійної відповідальності; продемонстровано їх взаємозалежність та взаємозумовленість. Презентовано програму розвитку професійної відповідальності студентів; подано ії мету, завдання, методологічну основу, розкрито специфіку формувального впливу.
\end{abstract}

Ключові слова: професійна відповідальність, сочіально-відповідальна поведінка, вольові якості, локус контролю, почуття совісності, саморегуляиія поведінки.

\section{Постановка проблеми у загальному} вигляді та їі зв'язок із важливими науковими чи практичними завданнями. Головним напрямом розвитку ракетно-космічної галузі в Україні $є$ формування економічно стійкої, конкурентоспроможної промисловості та інфраструктури, оскільки загальносвітові тенденції характеризуються підвищенням ролі космосу для суспільства. Досягнення цих цілей реально завдяки підвищення професіоналізму працівників та виховання потужного кадрового потенціалу - майбутніх фахівців ракетнокосмічної галузі. Підвищення ефективності та оптимізація діяльності фахівця можливі шляхом вдосконалення його психічної організації: свідомої регуляції і самоконтролю суб'єкта діяльності, підвищення ролі ділової активності і свідомого відповідального ставлення до поставлених завдань, процесу і результату діяльності. 
Для фахівців ракетно-космічної галузі високий рівень розвитку професійної відповідальності має виключне значення у зв'язку із складністю діяльності. Процес створення та функціонування складних технічних комплексів, таких як літальні апарати, повинен бути надійним та безпечним для людей і навколишнього середовища. В зв'язку із цим виникає необхідність розробки практичних заходів цілеспрямованого розвитку професійної відповідальності в майбутніх фахівців ракетнокосмічної галузі.

Аналіз останніх досліджень і публікацій, в яких започатковано розв'язання проблеми і на які спирається автор. Українськими та зарубіжними науковцями вивчалися: соціально-психологічні механізми формування професійної відповідальності колективних суб'єктів управління (С. Баранова); відповідальність як зв'язок між індивідом і колективом (О. Іваненко); психологічні детермінанти відповідальності менеджерів (В. Лазорко); процес становлення відповідальності як професійно значущої якості соціального працівника (О. Патинок); зв'язок відповідальності 3 рольовими професійними обов'язками (К. Муздибаєв); питання смислового змісту феномену (В. Бодров, О. Луценко); відповідальність в контексті особистісної властивості активного суб'єкта життедіяльності (Л. Дементій).

Виділення невирішених раніше частин загальної проблеми, яким присвячусть- ся означена стаття. Незважаючи на представленість широкого спектру досліджень окремих аспектів професійної відповідальності, аналіз літератури засвідчив відсутність наукових праць, в яких би висвітлювалася проблема вивчення психологічних умов, що сприяють розвитку професійної відповідальності фахівців ракетно-космічної галузі, а також розробки на цій основі практичних заходів цілеспрямованого розвитку їх професійної відповідальності у системі професійної освіти.

Мета статті - презентувати модель розвитку професійної відповідальності майбутніх фахівців ракетно-космічної галузі.

Виклад основного матеріалу дослідження 3 обгрунтуванням отриманих наукових результатів. Аналіз результатів проведеного нами емпіричного дослідження засвідчив недостатній рівень розвитку професійної відповідальності в майбутніх фахівців ракетно -космічної галузі (базовий - в студентів I курсу; виконавчий - в студентів II - IV курсів). Так, для більшості студентів характерне засвоєння в ході навчання норм та правил професійної діяльності фахівця ракетно-космічної галузі; вибіркова суб'єктивація мотивів та цінностей професійно відповідальної поведінки (помірно-позитивне ставленням до професійних обов'язків та відповідальності перед соціумом, невизначеність професійних планів); дотримання професійних норм, планування діяльності без прояву активності та ініціативності у вирішенні організаційних питань. За- 
значене обумовило необхідність розробити експериментальну модель та обгрунтувати програму розвитку професійної відповідальності в майбутніх фахівців ракетно-космічної галузі.

При моделюванні процесу розвитку професійної відповідальності ми виходили 3 припущення, що цілеспрямований психологопедагогічний вплив на розвиток професійної відповідальності майбутніх фахівців ракетнокосмічної галузі, який буде здійснено через актуалізацію визначених психологічних умов та впровадження розвивальної програми, буде сприяти досягненню позитивної динаміки розвитку структурних компонентів професійної відповідальності.

При розробці моделі нами також враховуються основні положення психологічних теорій відповідальності (Б. Г. Ананьєв, К. О. Абульханова-Славська, I. Д. Бех, А. В. Брушлинський, Л. І. Дементій, Г. С. Костюк, Л. П. Татомир, Т. М. Титаренко, К. К. Муздибаєв, М. В. Савчин, Дж. Роттер, К. Роджерс, А. Маслоу); наукові уявлення про закономірності розвитку особистості студентського віку (Б. Г. Ананьєв, І. М Іллінський, Е. Еріксон, I. С. Кон, О. В. СкоринінаПогребна, Г. Г. Петрученя) та професійний розвиток (Н. Ю. Волянюк, Е. Ф. Зеєр, Є. О. Клімов, Ю. П. Поваренков, В. Д. Шадриков); теоретичні положення та концептуальні засади дослідження і розвитку професійної відповідальності (В. О. Бодров, О. В. Лазорко,
О. П. Патинок， В.В.Пшенична, Н. М. Сатоніна).

Спираючись на вищенаведені підходи та дослідження, а також враховуючи результати констатувального експерименту, нами була запропонована експериментальна модель розвитку професійної відповідальності майбутніх фахівців ракетно-космічної галузі (Рис.1.).

Представлена модель дозволяє грунтовно пояснити реалізацію розробленої програми та наочно представити динамічний аспект розвитку професійної відповідальності, що виявляється у взаємозв'язку структурних елементів моделі - психологічних умов розвитку, тематичних блоків та розвивальних заходів програми, психологічної структури професійної відповідальності, критеріїв розвитку її компонентів.

Структурними компонентами експериментальної моделі є психологічні умови розвитку професійної відповідальності, які мають бути створені та реалізовані в процесі професійної підготовки фахівців ракетно-космічної галузі. На основі теоретичного аналізу психологічних характеристик професійної діяльності та його узгодження із структурою професійної відповідальності, - до цих умов було віднесено: усвідомлення відповідальності як професійно значущої якості фахівця ракетнокосмічної галузі; розвиненість мотивів соціально-відповідальної поведінки; вираженість вольових якостей особистості; інтернальність суб'єктивного контролю в професійній діяль- 


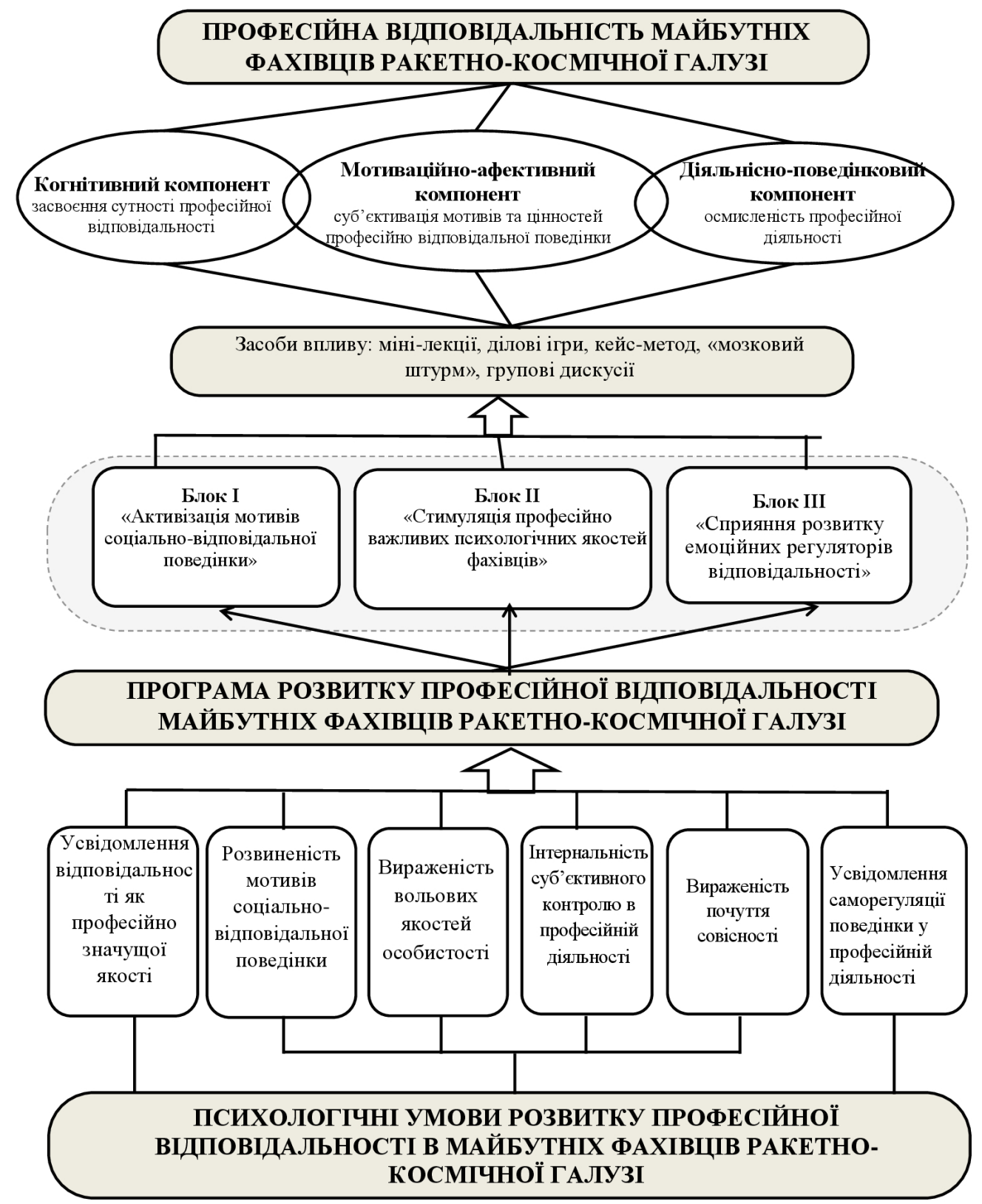

Рис.1. Модель розвитку професійної відповідальності майбутніх

\section{фахівців ракетно-космічної галузі}

ності; вираженість почуття совісності; усвідомлення саморегуляції поведінки у професійній діяльності.
Реалізація програми розвитку професійної відповідальності майбутніх фахівців ракетно-космічної галузі передбачає, що ви- 
значені умови є взаємопов'язаними, взаємозалежними та взаємозумовленими. Так, усвідомлення відповідальності як професійно значущої якості (когнітивний компонент) спряє прийняттю майбутнім фахівцем професійних норм, правил, обов'язків, необхідності їх реалізації в рамках певної професійної ролі, усвідомленню власних професійно-важливих якостей, тобто призводить до суб'єктивації мотивів та цінностей професійної відповідальності. Прийняття відповідальності на особистісному рівні впливає на вироблення громадянської позиції, етичної поведінки, відчуття обов'язку перед собою та суспільством за результати професійної діяльності (мотиваційноафективний компонент) [1]. В свою чергу, вироблення індивідуальної системи смислів професійно-відповідальної поведінки призводить до підвищення рівня самоконтролю і самоорганізації особистості, самомобілізацію внутрішніх зусиль, спрямованих на розвиток професійної відповідальності, сприяє усвідомленню залежності життєдіяльності індивіда від суспільних цілей та цінностей, професійній рефлекciї [5]. Все це активізує вироблення фахівцем оптимальної стратегії і тактики діяльності, прояв творчого характеру активності (діяльнісно-поведінковий компонент). Отже, цілеспрямована актуалізація зазначених умов у процесі професійної підготовки може сприяти більш успішному розвитку професійної відповідальності в майбутніх фахівців ракетнокосмічної галузі.
Визначені умови узгоджуються зі структурною організацією професійної відповідальності майбутніх фахівиів ракетнокосмічної галузі, яка, грунтуючись на концептуальних положеннях О. П. Патинок [3], включає когнітивний (система засвоєних особистістю знань про сутність професійної відповідальності та їх усвідомлення), мотиваційно-афективний (індивідуальна система мотивів і смислів соціально-відповідальної поведінки, емоційні переживання, які регулюють професійну відповідальність, професійноважливі якості фахівця ракетно-космічної галузі) та діяльнісно-поведінковий (вибір та peaлізація певної лінії поведінки та вчинків у професійних ситуаціях) компоненти.

У запропонованій моделі також представлено критерії розвитку професійної відповідальності майбутніх фахівців ракетнокосмічної галузі, які були виділені нами на констатувальному етапі експериментального дослідження з урахуванням результатів теоретичного аналізу досліджуваної проблеми та наукових розробок щодо структури професійної відповідальності [3; 5]. Виокремлені критерії співвідносяться зі структурою професійної відповідальності майбутніх фахівців ракетно-космічної галузі, а наявність позитивної динаміки числових показників студентів за цими критеріями може свідчити про активний процес розвитку професійної відповідальності. Так, про розвиненість когнітивного компонента може свідчити засвоєння студентами 
сутності професійної відповідальності (I. А. Гамула, О. П. Патинок, Л. А. Сатановська), тобто поступове опанування студентами в ході навчальної діяльності знань про сутність професійної відповідальності, норм та правил, які регулюють професійну діяльність фахівця ракетно-космічної галузі. Критерієм розвитку мотиваційно-афективного компонента слід вважати суб'єктивацію мотивів та иүінностей професійно відповідальної поведінки (О. В. Лазорко, Г. М. Йонас, А. О. Орлов, М. В. Савчин, Н. М. Сатоніна, Ю. О. Сичевський), тобто вироблення індивідуальної системи смислів професійно відповідальної поведінки, усвідомлення власних професійно-важливих якостей та відповідальності перед соціумом і навколишнім середовищем, відчуття відповідальності за дотримання професійних норм та обов'язків. Для діяльнісноповедінкового компонента критерієм розвитку, на основі досліджень В. А. Бодрова, Л. І. Дементій, М.В.Савчина, В.В.Шусть, може виступати осмисленість професійної діяльності - вибір та реалізація певної лінії поведінки та вчинків у професійних ситуаціях у зв'язку з нормами відповідальності, які зумовлені індивідуальною системою цінностей та смислів. Однак результати констатувального етапу дослідження засвідчили недостатній рівень розвитку професійної відповідальності та необхідність розробки і впровадження практичних заходів іiі цілеспрямованого розвитку в майбутніх фахівців ракетно-космічної галузі.

Відповідно до експериментальної моделі розроблено програму розвитку професійної відповідальності майбутніх фахівців ракетно-космічної галузі. Метою програми визначено здійснення систематичного і цілеспрямованого впливу на розвиток професійної відповідальності майбутніх фахівців ракетнокосмічної галузі за рахунок створення та реалізації спеціальних психологічних умов у процесі навчальної діяльності.

Основними завданнями програми розвитку професійної відповідальності визначено наступні:

- активізувати в студентів потребу в розвитку професійної відповідальності;

- забезпечити засвоєння теоретичних знань щодо сутності професійної відповідальності, її складових та особливостей розвитку; - забезпечити адаптивну функцію професійної підготовки майбутніх фахівців ракетно-космічної галузі, пов'язану з набуттям студентами вмінням саморегуляції та реалізації відповідальної поведінки у професійних ситуаціях;

- формування мотиваційної настанови на подальший розвиток професійно важливих якостей, зокрема, відповідальності в професійній діяльності.

Методологічну основу розвивальної програми склали положення компетентнісного (I. Д. Бех; Н. М. Бібік, О. В. Овчарук; В. О. Болотов; М. Б. Свтух; І. Г. Срмаков; 
I. О. Зимняя; О. І. Локшина; О. I. Пометун; В. О. Радкевич; О. Я. Савченко; Ю. Ф. Фролов; А. В. Хуторський; Н. В. Чепелєва), особистісно діяльнісного (Г. О. Балл; І. С. Булах; Л. В. Долинська; І. О. Зимняя; С. Д. Максименко; А. К. Маркова; С. Л. Рубінштейн; В. В. Сєріков; В. О. Татенко; Т. В. Тихонова; Ю. М. Швалб; І. С. Якиманська), аксіологічного (В. П. Андрущенко; Б. С. Гершунський; $\begin{array}{ll}\text { I. А. Зязюн; } & \text { В. П. Зінченко; } \\ \text { В. В. Крижко; }\end{array}$ $\begin{array}{lll}\text { O. А. Листопад; } & \text { В. О. Сластьонін; }\end{array}$ Н. О. Ткачова; А. О. Ярошенко), акмеологічного (О. О. Бодальов; В. М. Вакуленко; А. О. Деркач; Н. В. Кузьміна; С. С. Пальчевський) підходів та провідні принципи навчально-виховної та тренінгової роботи (науковості, системності та послідовності, індивідуалізації, гуманізму та демократизації, свідомості та активності, оптимізації).

В запропонованій моделі представлено три основні блоки, зміст яких здійснює цілеспрямоване посилення визначених нами психологічних умов. Оскільки мотиваційноафективний компонент $є$ системоутворювальним компонентом професійної відповідальності, формувальний вплив здійснювався, перш за все, через актуалізацію мотивів соціальновідповідальної поведінки, психологічних якостей студентів (вольові якості, інтернальність суб'єктивного контролю), почуття совісності як емоційного регулятора відповідальності. Розвиток когнітивного та діяльнісноповедінкового компонентів, які концентру- ються навколо мотиваційно-афективного, забезпечувався за рахунок включення до кожного модулю програми тематичних блоків, спрямованих на усвідомлення досліджуваними відповідальності як професійно значущої якості, саморегуляції поведінки у професійній діяльності.

Перший блок спрямований на активізаціюо мотивів сочіально-відповідальної поведінки студентів. Соціальна відповідальність виявляється способом свідомої психологічної регуляції діяльності, яка проявляється у дотриманні норм й інтересів суспільства, та виступає важливим напрямом підготовки фахівців технічних спеціальностей.

Другий блок націлений на стимулящ̧ію професійно важливих психологічних якостей фахівиів. Становлення професійної відповідальності нерозривно пов'язане із рівнем суб'єктивного контролю, який, як інтегральна риса індивіда сполучає між собою почуття відповідальності, усвідомлення сенсу життя, готовність до активності. Важливим завданням розвитку професійної відповідальності має бути стимулювання змін в емоційній, вольовій та поведінковій сферах особистості, віднаходження адекватного пояснення власних невдач, моделювання навичок наполегливості у подоланні труднощів.

Метою третього блоку є сприяння розвитку емоиійних регуляторів відповідальнос$m i$. Усвідомлення майбутніми фахівцями інженерних спеціальностей об'єктивних крите- 
ріїв морального сенсу суспільного блага, внутрішнє усвідомлення свого професійного обов'язку створюють правильні світоглядні орієнтири, які виступають підгрунтям оцінювального ставлення до своїх вчинків в професійній діяльності.

Формувальний вплив на розвиток професійної відповідальності студентів здійснювався за допомогою професійнопсихологічного тренінгу (ППТ). Вибір такої форми організації навчальної діяльності студентів із-поміж інших зумовлений низкою причин. Цей вид тренінгу заповнює проміжок між функціональним (доведення до автоматизму професійно необхідних умінь та навичок) i власне психологічним тренінгом (проробка актуальних психологічних проблем, саморозвиток учасників) й визначається як навчальнорозвивальна технологія, метою якої є формування професійних знань та умінь, становлення особистості як суб'єкта професійної діяльності [2].

Стрижневим моментом при розробці психолого-педагогічної програми стало визначення адекватних розвивальних заходів. Враховуючи специфіку структурної організації професійної відповідальності, модулі програми та тематичні блоки було побудовано таким чином, щоб сприяти процесу інтеріоризації зовнішнього професійного контексту: від теоретичних повідомлень у формі міні-лекцій та пропонованих зразків поведінки і діяльності (методичний блок) - до їх усвідомлення i включення у пізнавальні та регулятивні структури психіки у вигляді умінь, навичок, настанов щодо відповідальності в професійній діяльності (практичний блок). У практичному блоці сприяння розвитку професійної відповідальності здійснювалося головним чином через застосування комплексу психотехнічних та імітаційних тренінгових методів (рольові ігри, кейс-метод) - 3 метою розвитку професійного мислення, здібності аналізувати професійну ситуацію, формування навичок прийняття рішень за допомогою імітації конкретних умов професійної діяльності. Серед інших засобів впливу - технології арт-коучинга, дискусії, метод мозкового штурму, виконання психодіагностичних методик, метод метафори (аналіз притч).

В рамках професійно-психологічного тренінгу нами застосовувались технології арткоучингу, головна мета якого полягає в гармонізації розвитку особистості через розвиток здібностей творчого самовираження і самопізнання у професійній діяльності. Унікальність методу арт-терапії в роботі з персоналом багато в чому пояснюється тим, що арт-терапія метод художньої терапії, заснований на злитті творчості і терапевтичної (або консультаційної) практики, спрямований на корекцію емоційної, мотиваційної, комунікативної, регулятивної сфер, і сприяє розвитку особистості. Цей метод надає можливість для дослідження несвідомих процесів і настанов, вираження тих непроявлених можливостей, соціальних 
ролей і форм поведінки, які з різних причин слабо виражені і реалізовані в особистому житті і професійній діяльності людини [4, с. 67].

Для розвитку моральних складових професійної відповідальності (соціальна відповідальність, громадська свідомість, моральні свідомість, етика відповідальності) ми також використовували метод метафори, зокрема, аналіз притч та розповідей, вирішення моральних дилем. Метод метафори, на думку багатьох авторів $\epsilon$ ефективним методом аналізу та осмисленню категорій етики, сприяє розширенню свідомості людини за кордони звичних рамок, стереотипів та шаблонів мислення, формальної логіки.

Отже, запропонована експериментальна модель та розроблена на іiї основі комплексна програма передбачають актуалізацію визначених психологічних умов, що може сприяти розвитку професійної відповідальності майбутніх фахівців ракетно-космічної галузі в процесі професійної підготовки.

Висновки і перспективи подальшого дослідження. В статті обгрунтовано необхідність розробки моделі та впровадження на іiі основі програми цілеспрямованого розвитку професійної відповідальності майбутніх фахівців ракетно-космічної галузі у зв'язку з превалюванням тенденції до формального ставлення до професійних обов'язків. На підставі теоретичних та емпіричних засад дослідження побудовано модель розвитку професійної від- повідальності майбутніх фахівців ракетнокосмічної галузі, яка містить психологічні умови, тематичні блоки та розвивальні заходи програми, психологічну структуру професійної відповідальності, критерії розвитку їі компонентів.

Перспективним напрямом розвитку наукової проблематики надалі вбачається подальша розробка та апробація програми розвитку професійної відповідальності майбутніх фахівців ракетно-космічної галузі за рахунок актуалізації визначених психологічних умов.

\section{Перелік використаних джерел:}

1. Ковальчук O. С. Розробка опитувальника для виміру соціальної відповідальності інженера / О.С. Ковальчук, Ю.В. Проскура // Актуальні проблеми психології : зб. наук. пр. Інституту психології ім. Г.С. Костюка НАПН України, 2010. - Т.1. - Ч. 25/26. - С. 282-288.

2. Мороз Л. I. Тренінги як засіб розвитку професійно значущих та особистісних якостей / Л. І. Мороз // Bicник Київського національного університету імені Тараса Шевченка. Військово-спеціальні науки. - 2009. Вип. 23. - С. 55-57.

3. Патинок О. П. Становлення відповідальності як професійно значущої якості соціального працівника : автореф. дис. ... канд. психол. наук: 19.00.07 / Патинок Оксана Петрівна ; Нац. пед. ун-т ім. М.П. Драгоманова. K., 2008. - 20 c.

4. Тарарина E. ART-коучинг. Техники пРОСТых решений / Е. Татарина. К. : САММИТ-КНИГА, 2015. - 88c.

5. Шевченко Н. Ф. Характеристика професійної відповідальності фахівця авіаційної та ракетно-космічної техніки / Н.Ф. Шевченко, Н.П. Крошка / Проблеми сучасної психології: збірник наукових праць Запорізького національного університету та Інституту психології 
імені Г.С. Костюка НАПН України. - Запоріжжя: ЗНУ, 2016. - № 2 (10) - C.137-144.

\section{References (Transliteration):}

1. Koval'chuk O. S. Rozrobka opytuval'nyka dlya vymiru sotsial'noyi vidpovidal'nosti inzhenera [Development of a questionnaire for measuring $\mathrm{CR}$ of an Engineer] / O.S. Koval'chuk, Yu.V. Proskura // Aktual'ni problemy psykholohiyi : zb. nauk. pr. Instytutu psykholohiyi im. H.S. Kostyuka NAPN Ukrayiny, 2010. - T.1. - Ch. 25/26. - P. 282-288.

2. Moroz L. I. Treningi yak zasib rozvy`tku profesijno znachushhy`x ta osoby`stisny`x yakostej [Training as a means of developing professionally meaningful and personal qualities] / L. I. Moroz // Visny`k Ky`yivs`kogo nacional'nogo universy`tetu imeni Tarasa Shevchenka. Vijs`kovo-special`ni nauky`. - 2009. - Vy`p. 23. - P. 5557.

3. Patynok O. P. Formation of responsibility as a professional significant quality of social worker [Formation of responsibility as a professional significant quality of social worker]: avtoref. dys. ... kand. psykhol. nauk: 19.00.07 / Patynok Oksana Petrivna ; Nats. ped. un-t im. M.P. Drahomanova. - K., 2008. - 20 p.

4. Tararina E. ART-kouching. Tehniki pROSTyh reshenij [ART-coaching. Techniques of simple solutions] / E. Tatarina. K. : SAMMIT-KNIGA, 2015. - 88p.

5. Shevchenko N. F. Kharakterystyka profesiynoyi vidpovidal'nosti fakhivtsya aviatsiynoyi ta raketnokosmichnoyi tekhniky [Characteristics of the professional responsibility of a specialist of the aviation and rocket-andspace machinery] / N.F. Shevchenko, N.P. Kroshka / Problemy suchasnoyi psykholohiyi: zbirnyk naukovykh prats' Zaporiz'koho natsional'noho universytetu ta Instytutu psykholohiyi imeni H.S. Kostyuka NAPN Ukrayiny. Zaporizhzhya: ZNU, 2016. - \# 2 (10) - P.137-144.

\section{Kroshka Nataliia}

PhD student of Psychology Department of Zaporizhzhya National University, Zaporizhzhya (Ukraine)

\section{DEVELOPMENT MODEL OF PROFESSIONAL RESPONSIBILITY OF FUTURE SPECIALISTS OF THE ROCKET-AND-SPACE TECHNOLOGY}

\section{ABSTRACT}

The author of the article substantiates the need for elaboration and implementation of the model and the program of the telic development of the professional responsibility of future specialists of the rocket-and-space technology. Based on the theoretical foundations of the research, a development model of the professional responsibility of future specialists of the rocket-and-space technology has been built. The model includes psychological conditions of development, thematic blocks and developing measures of the program, psychological structure of the professional responsibility, development criteria of its components. The structural components include: cognitive, motivational-and-affective and actionbehavioral. The dynamical aspect of the professional responsibility development, which is embodied in the relationship of all components of the model, has been revealed. In the article there have been considered psychological conditions of development of the professional responsibility of rocket-and-space technology specialists: recognition of responsibility as a professionally significant quality; developing of socially responsible behavior motives; intensity of the volitional qualities of a personality; internality of the subjective 
control; intensity of a sense of conscience; awareness of the behavior self-regulation in professional activities. The interdependence and the conditionality of these conditions has been demonstrated. The model contains development criteria of the professional responsibility of future specialists of the rocket-and-space technology. The criteria include the following: assimilation of the meaning of the professional responsibility; subjectification of the motives and values of the professional responsible behavior; self-awareness of the professional activities. The program of the development of the professional responsibility of future specialists of the rocket-and-space technology has been presented. The content of the program includes its goal and objectives, methodological framework, specifics of the developing measures by means of the professional- psychological training. Promising directions of further researches concern further elaboration and implementation of the development program of the professional responsibility of future specialists of the rocket-and-space technology; presentation of the approbation results of the elaborated program.

Key words: professional responsibility, socially responsible behavior, volitional qualities, locus of control, a sense of conscience, selfregulation of the behavior.

\section{Крошка Наталия Петровна}

Аспирант кафедры психологии Запорожского нациионального университета, г. Запорожье (Украина)

\section{МОДЕЛЬ РАЗВИТИЯ ПРОФЕССИО- НАЛЬНОЙ ОТВЕТСТВЕННОСТИ У БУДУЩИХ СПЕЦИАЛИСТОВ РАКЕТНО-КОСМИЧЕСКОЙ ОТРАСЛИ}

Аннотация. В статье обоснована необходимость разработки модели и внедрения программы целенаправленного развития профессиональной ответственности у будущих специалистов ракетно-космической отрасли. На основе теоретических положений исследования предложено экспериментальную модель развития профессиональной ответственности у будущих специалистов ракетнокосмической отрасли. Модель содержит психологические условия, тематические блоки и развивающие мероприятия программы, психологическую структуру профессиональной ответственности, критерии развития ее компонентов (когнитивного, мотивационноаффективного, деятельностно-поведенческого). Раскрыт динамический аспект развития профессиональной ответственности, который проявляется во взаимосвязи всех составляющих модели. Рассмотрены психологические условия развития профессиональной ответственности будущих специалистов ракетнокосмической отрасли: осознание ответственности как профессионально значимого качества; развитость мотивов социальноответственного поведения; выраженность волевых качеств личности; интернальность 
субъективного контроля; выраженность чувства совестливости; осознание саморегуляции поведения в профессиональной деятельности. Продемонстрирована их взаимозависимость и взаимообусловленность. В модели представлены критерии развития профессиональной ответственности: усвоение сущности профессиональной ответственности, субъективация мотивов и ценностей профессионально ответственного поведения, осмысленность профессиональной деятельности. Представлена программа развития профессиональной ответственности студентов: ее цель, задания и методологическая основа, раскрыта специфика формирующего воздействия. Перспективным направлением развития научной проблематики определено дальнейшая разработка и апробация программы развития профессиональной ответственности у будущих специалистов ракетно-космической отрасли за счет актуализации выделенных психологический условий.

Ключевые слова: профессиональная ответственность, социально-ответственное поведение, волевые качества, локус контроля, чувство совестливости, саморегуляция поведения. 